Relations industrielles

Industrial Relations

\title{
Labour Relations Techniques
}

\section{Gérard Tremblay}

Volume 4, numéro 8, avril 1949

URI : https://id.erudit.org/iderudit/1023518ar

DOI : https://doi.org/10.7202/1023518ar

Aller au sommaire du numéro

Éditeur(s)

Département des relations industrielles de l'Université Laval

ISSN

0034-379X (imprimé)

1703-8138 (numérique)

Découvrir la revue

Citer cet article

Tremblay, G. (1949). Labour Relations Techniques. Relations industrielles /

Industrial Relations, 4(8), 71-72. https://doi.org/10.7202/1023518ar

Tous droits réservés @ Département des relations industrielles de l’Université Laval, 1949
Ce document est protégé par la loi sur le droit d'auteur. L'utilisation des services d'Érudit (y compris la reproduction) est assujettie à sa politique d'utilisation que vous pouvez consulter en ligne.

https://apropos.erudit.org/fr/usagers/politique-dutilisation/ 


\section{Bulletin des relations industrielles}

Volume 4, number 8

Published by the

\section{Department of Industrial Relations, Faculty of Social Sciences, Laval University. \\ Georges-Henra Levesque, o.p., Dean GERARd TrEmblay, Director GÉrard Dion, Assistant-Director Jean Gagné, Secretary \\ Charles Bélanger, Administrator}

The Bulletin is published monthly, September to June inclusively (ten issues a year). Annual subscription: Canada: $\$ 2.00$; Foreign: \$2.50. Single copies: twenty-five cents.

$$
\begin{aligned}
& \text { Publication indexed in the } \\
& \text { "Canadian Index". }
\end{aligned}
$$

All correspondance must be addressed to the Literary Editor Gerard Dion

2, University Street, Quebec.

\begin{tabular}{cc}
\hline Bulletin des relations industrielles \\
\hline Volume 4, number 8 & April 1949 \\
\multicolumn{3}{c}{ Contents }
\end{tabular}

Labour Relations Techniques Gérard Tremblay. 71

The Application of the Collective Agreement and Personnel

Administration

Jean GaGNÉ.. '..

Labour-Management Committees.. ..

Salary Trends of Employees of the Wholesale Food Trade of Ouebec

Raymond GaGné..

The Term of Notice..

$\begin{array}{lllllllllll}\text { Structural Reform.. } & . . & . . & . . & . . & . . & . . & . . & . . & 78\end{array}$

Arbitration Procedure

Its use in the Province of Quebec.

\section{Contributors}

GAGNÉ, Jean, B.A., M.ScSoc., LL.L., Secretary of the Department of Industrial Relations of Laval University.

Gagné, Raymond, B.A., M.Sc.Soc., Statistician, Wholesale Food Trade Parity Committee of Quebec.

Tremblay, Gérard, L.Ph., Deputy-Minister of Labour, Professor in the Faculty of Social Sciences and Director of the Department of Industrial Relations of the Faculty of Social Sciences of Laval University.

Authorized as second class mail Post-office Department, Ottawa, Canada.
QUEBEC

April 1949

\section{LABOUR RELATIONS TECHNIQUES}

\author{
Gérard Tremblay
}

《Labour Relations Techniques》. This is the theme of the fourth Convention of the Industrial Relations Department. This theme follows logically after that of last year \& Forms of employer-employee cooperation». One of the present well-recognized forms of this cooperation is certainly the collective negotiation of working conditions which gives birth to the collective agreement itself. Now, if we have studied the collective agreement last year, a good example of employer-employee cooperation, is it not appropriate that we disclose now the techniques? Techniques of the collective agreement or techniques of labour relations, on a larger scale, are the methods of solving the same problem.

Labour relations are precisely those human relations which necessarily develop between capital and labour in the process of production and distribution of goods. Now, the collective agreement is also the expression of human relations between the employer and the employees' union. And it happens that the contents of the agreement indicate also the norms which must be followed by both parties in the work of production and the sharing of the plus-value added to the raw material by their common efforts.

This parallelism of the definition of labour relations and of the collective agreement has not always been possible. In the last century labour relations were almost always maintained in the framework of individual relations. But the evolution has been made and is continuing from the individual to the collective.

There is to-day a legal system of collective agreements. This is recognized as of common good by the law in all of Canada as well as in the United States and democratic Europe. Employees and employers no longer put in doubt its excellence, even if the agreement is only reached with much difficulty. Labour relations more and more bring us back to the collective agreement, so much so, that one might say: give me good collective agreements and I assure you.will have good labour relations. 
However, these good labour relations presuppose the use of good techniques. And these techniques are not only a clever codification of laws and of customs. They are first of all human, because they concern all of man, his thoughts, his conscience, his instincts, his needs, his life. And we must admit that the techniques of labour re lations have firstly a human and moral aspect, which is less apparent but which goes beyond the scientific and legal aspect. That, to which we must strain, is the integration in the minds and hearts of men of these many aspects of a complex yet simple probiem: the problem of man in his relations with his fellow-men in face of his economic actjvities.

During this Convention, will be discussed the complete cycle of labour relations: organization of workers' union and employers' association. Both are necessary. Social norms cannot be established in a world that is individualistic and not organized. It would be a system of chaos and of incoherence. A certain parallel must be kept between the workers' and employers' organizations. It is not logical to oblige a trade-union to negotiate with a heteroclite employers' association.

There is therefore a technique of organization which must take into account the particularities of community of work.

These organizations must, through their representatives, prepare and conclude the agreements; they must apply the provisions. We are here at the very heart of labour relations. Direct negotiations are best; they prevent long drawnout recourse to conciliation, mediation and arbitration. It is in the negotiations that one judges the qualities of the representative of the union and of the employers. Qualities of mind and heart. Integrity of thought, understanding, loyalty, patience and firmness; knowledge of the elements in question, techniques of industry, market conditions; persuasive and illuminating speech. It will not be forgotten during these days of study to throw light on the necessity of developing these qualities and many others in the responsible persons.

Procedures of conciliation, mediation and arbitration will be, I believe, always necessary, although the use of them may be reduced as the interested parties develop their sense of responsibility. Therefore, it would be opportune to have a look at the techniques which must govern our use of them. Conciliation is a more advanced stage of negotiation. A third person intervenes in order to better direct the debate, to suggest the compromise which had not been found and which will permit the safeguard of all prestige. The conciliator must develop in himself all the qualities that are required in the negotiator. The mediator, who is placed on a higher moral plane, must also call on all the resources of psychology, of dialectics and a high sense of justice, if he wishes to get the two parties to accept his proposals. The arbitration procedure has also its dangers not only for the arbitrators but also for the delegates of the parties who must take part in the procedures. Carefulness in the choice of a president, well-defined matter to be settled, appearan. ce of witnesses and experts, preparation of proof and statement, pleadings, these are many subjects for study by the technicians of labour relations.

Where must the effort to improve the techniques lead us ? Simply to convince us that first of all competence cannot be improvised, but must be prepared with effort; that there is, because of the industrialization of the province and of the development of the collective relations between employers and employees and also because of a more advanced legislation, a more and more pressing need of good specialists in industrial relations who must integrate a social sphere where they can help the common good in serving judicially a group.

Good labour relations helped by proved techniques will finally permit the assurance of the dignity of the workingman, favour the equitable distribution of wealth which the Church recommends and which the people demand and to secure for our country the social peace which results from justice and charity. 